\title{
PENGUJIAN AKTIVITAS ANTIBAKTERI SABUN CAIR DARI EKSTRAK ETANOL BUAH PEPAYA (Carica papaya L) PADA BAKTERI Staphylococcus aureus
}

\author{
Ratih Paramitha $^{1^{*}}$, Athaillah ${ }^{1}$, Robiatun Rambe ${ }^{1}$, Selvina $^{1}$ \\ ${ }^{1}$ Universitas Haji Sumatera Utara, Medan, Indonesia \\ *E-mail: mitha25.paramitha@gmail.com
}

\begin{abstract}
Abstrak
Buah pepaya (Carica papaya L) merupakan tanaman tropis yang dapat digunakan sebagai tanaman obat. Buah pepaya memiliki kandungan nutrisi, enzim papain dan senyawa aktif flavonoid, tanin, saponin dan alkaloid. Senyawa aktif buah pepaya diketahui memiliki efek antibakteri. Penelitian ini bertujuan untuk mengetahui aktivitas antibakteri ekstrak buah pepaya dalam sediaan sabun cair terhadap bakteri gram positif Staphylococcus aureus. Ekstrak buah pepaya dibuat dengan metode maserasi menggunakan pelarut etanol 96\%. Selanjutnya ekstrak tersebut diformulasikan menjadi sediaan sabun cair berbagai formulasi F0, F1, F2, F3, F4, F5, dengan variasi konsentrasi ekstrak F0 (0\%), F1 (20\%), F2 (30\%), F3 (40\%), F4 (50\%), F5 (60\%). Evaluasi sediaan yang dilakukan berdasarkan SNI 06-4085-1996 meliputi pemeriksaan organoleptik, penentuan nilai $\mathrm{pH}$ dan bobot jenis. Pengujian aktivitas antibakteri sabun cair dilakukan dengan metode difusi. Hasil menunjukan bahwa sabun telah memenuhi standar yang ditetapkan yaitu berbentuk cairan homogen, berwarna coklat tua, berbau khas pepaya, $\mathrm{pH} 7$, bobot jenis 1,02-1,04 g/ml. Aktivitas antibakteri terhadap bakteri Staphylococcus aures yang paling efektif adalah pada F2 (30\% b/v) dengan daya hambat $17,6 \mathrm{~mm}$.
\end{abstract}

Kata kunci: buah pepaya (Carica papaya L.), sabun cair, antibakteri, Staphylococcus aures.

\begin{abstract}
Papaya (Carica papaya L) is a tropical plant that can be used as a medicinal plant. Papaya contains nutrients are papain enzymes and active compounds such as flavonoids, tannins, saponins and alkaloids. The active compound of papaya was known as an antibacterial. This study aimed to determined the antibacterial activity of papaya extracts in liquid soap against gram positive bacteria Staphylococcus aureus. Papaya extract was made by maceration method using 96\% ethanol solvent. Furthermore, the extract was formulated into liquid soap preparations of various formulations $F 0, F 1, F 2, F 3, F 4, F 5$, with variations in the concentration of extracts $F 0$ (0\%), F1 (20\%), F2 (30\%), F3 (40\%), F4 (50\%), F5 (60\%). Evaluation of preparations made based on SNI 06-4085-1996 includes organoleptic examination, determination of $\mathrm{pH}$ values, and specific gravity. Testing the antibacterial activity of liquid soap was done diffusion method. The results showed that the soap meets the established standards homogeneous liquid, dark brown, distinctively smelling papaya, $\mathrm{pH} 7$, specific gravity $1.02-1.04 \mathrm{~g} / \mathrm{ml}$. The most effective antibacterial activity against Staphylococcus aures is formula 2 with a resistance of $17.6 \mathrm{~mm}$.
\end{abstract}

Keywords: papaya (Carica papaya L.), liquid soap, antibacterial, Staphylococcus aures.

\section{Pendahuluan}


Tanaman pepaya merupakan tanaman yang banyak diteliti saat ini karena hampir seluruh bagian dapat dimanfaatkan baik daun, getah, biji, akar, batang, dan buahnya. Tanaman pepaya termasuk kedalam suku Caricaceae marga Crica yang berasal dari Amerika tropis dan cocok untuk ditanam di Indonesia. Bentuk daunnya majemuk dan menjari, buahnya berwarna kuning sampai jingga dengan daging buah lunak dan berair, jenis bunga pada tanaman pepaya adalah bunga jantan saja, betina saja, atau hemafrodit, memiliki saluran getah pada batang (Tjitrosoepomo G, 2005). Tanaman pepaya telah banyak digunakan oleh masyarakat sejak dulu. Secara empiris pepaya banyak digunakan sebagai diuretik (akar \& daun), anthelmintik (biji \& daun), dan untuk menyembuhkan penyakit akibat empedu (buah), serta dyspepsia dan kelainan pencernaan lainnya (Gill S, 2015).

Senyawa aktif yang terdapat pada tanaman pepaya yaitu enzim papain, karotenoid, alkaloid, monoterpenoid, flavonoid, mineral, vitamin, glukosinolat, karposidam(Milind P dan Gurditta, 2011). Berdasarkan hasil penelitian tanaman pepaya diketahui memiliki manfaat sebagai antikanker, antioksidan, antidiabetes, antifertilitas, antiinflamasi, anthelmintika, antibakteri, antimalaria, antidengue, dan penyembuh luka. Tanaman pepaya (Carica papaya L) memiliki kandungan papain, flavonoid, alkaloid, saponin, glikosida, dan senyawa fenol yang menyebabkan pepaya memiliki aktivitas antibakteri (Akujobi CN et.al., 2010). Ekstrak tanaman pepaya baik bagian daun, akar, maupun batangnya memiliki aktivitas antibakteri yang lebih baik pada ekstrak organik dibandingkan dengan ekstrak air dan lebih efektif terhadap bakteri gram negatif dibandingkan gram positif (Nirosha $\mathrm{N}$ and Manganalanayaki R, 2013). Namun pada penelitian Anibijuwon tahun 2009, ditemukan bahwa ekstrak akar pepaya lebih efektif aktivitas antibakterinya terhadap bakteri gram positif daripada negatif (Anibijuwon I.I and Udeze A.O, 2009). Aktivitas antibakteri tanaman pepaya meningkat pada suhu yang tinggi dan $\mathrm{pH}$ yang sama (J.H Dounghari et.al., 2007).

\section{Metode Penelitian}

Tempat Penelitian

Penelitian ini dilakukan dilaboratorium Mikrobiologi dan laboratorium teknologi sediaan farmasi Program Studi Farmasi Sekolah Tinggi Ilmu Kesehatan Nurliana Medan.

\footnotetext{
Alat dan Bahan

Alat yang digunakan adalah Gelas kimia $100 \mathrm{ml}, 250 \mathrm{ml}, 500 \mathrm{ml}$ (pyrex), gelas ukur 250 $\mathrm{ml}, 100 \mathrm{ml}, 50 \mathrm{ml}$ (pyrex), piknometer $5 \mathrm{ml}$ (pyrex), cawan petri kaca, hot plate, inkubator, jarum ose, kertas cakram, magnetic stirrer, neraca analitik, indikator universal, seperangkat alat rotary evaporator, colony counter.
}

Bahan yang digunakan dalam penelitian ini adalah Buah pepaya, bakteri Staphylococcus aureus, etanol 96\%, asam klorida (HCL) 1M, pereaksi mayer, pereaksi bouchardat, pereaksi dragendorff, serbuk Mg, amil alkohol, besi (III) klorida, Nutrien Agar (NA), Nutrien Broth (NB), Plate Counter Agar (PCA), minyak jarak, minyak zaitun, minyak kelapa, Kaliaum hidroksida (KOH), Hidroksipropil metilselulosa (HPMC), asam stearat, gliserin, Butylated hydroxytoluene (BHT).

\section{Prosedur Penelitian \\ Pembuatan simplisia buah pepaya (Carica papaya $\mathrm{L}$ ).}


Buah pepaya yang telah dikumpulkan kemudian dicuci, disortasi basah, dirajang tipis kemudian dikeringkan dengan cara diangin-anginkan di suhu kamar $\pm 20-25^{\circ} \mathrm{C}$. Simplisia yang sudah dikeringkan diblender sampai halus, lalu diayak menggunakan ayakan 40 mesh kemudian ditimbang.

\section{Skrining Fitokimia}

Skrining fitokimia serbuk simplisia buah pepaya meliputi, pemeriksaan senyawa alkaloid, saponin, flavonoid, dan tanin.

a. Pemeriksaan alkaloid

Serbuk simpllisia ditimbang sebanyak 0,5 g kemudian ditambahkan $1 \mathrm{ml}$ HCL $1 \mathrm{M}$ dan 9 $\mathrm{ml}$ etanol 96\%, dipanaskan di atas penangas air selama 2 menit, didinginkan lalu disaring. Filtrat dipakai untuk percobaan berikut:

- Diambil 3 tetes filtrat, lalu ditambahkan 2 tetes pereaksi Mayer

- Diambil 3 tetes filtrat, lalu ditambahkan 2 tetes pereaksi Bouchardat

- Diambil 3 tetes filtrat, lalu ditambahkan 2 tetes pereaksi Dragendorff

Alkaloida dianggap positif jika terjadi endapan atau paling sedikit dua atau tiga dari percobaan di atas (Depkes RI, 1995).

b. Pemeriksaan flavonoid

Sebanyak 10 g serbuk simplisia kemudian ditambahkan $100 \mathrm{ml}$ etanol $96 \%$, dididihkan selama 5 menit dan disaring dalam keadaan panas. Filtrat yang diperoleh kemudian diambil $5 \mathrm{ml}$ lalu ditambahkan $0,1 \mathrm{~g}$ serbuk $\mathrm{Mg}, 1 \mathrm{ml} \mathrm{HCl}$ pekat dan $2 \mathrm{ml}$ amil alkohol. Flavonoid positif jika terjadi warna merah, kuning, jingga pada lapisan amil alkohol (Farnsworth, 1966).

c. Pemeriksaan tanin

Sampel disari 0,5 g dengan $10 \mathrm{ml}$ aquades kemudian disaring, filtratnya diencerkan dengan air sampai tidak berwarna. Larutan diambil sebanyak $2 \mathrm{ml}$ dan ditambahkan 2 tetes pereaksi besi (III) klorida, jika terjadi warna hijau, biru kehitaman menunjukan adanya tanin (Farnsworth, 1966).

d. Pemeriksaan saponin

Sebanyak 0,5 sampel dimasukkan ke dalam tabung reaksi dan ditambahkan $10 \mathrm{ml}$ aquades panas, didinginkan kemudian dikocok kuat-kuat selama 10 detik, terbentuk buih atau busa tidak kurang dari 10 menit setinggi $1-10 \mathrm{~cm}$. Penambahan 1 tetes larutan asam klorida $2 \mathrm{~N}$, apabila buih tidak hilang menunjukkan adanya saponin (Depkes RI, 1995).

\section{Pembuatan Media}

Media nutrien agar (NA) sebanyak 23 gram dimasukkan kedalam erlenmeyer lalu dilarutkan dengan menambahkan $1 \mathrm{~L}$ aquades, kemudian dipanaskan hingga mendidih diatas hot plate sambil dihomogenkan dengan menggunakan magnetic stirrer. Media nutrien broth (NB) sebanyak 8 gram dimasukkan kedalam erlenmeyer lalu dilarutkan dengan menambahkan $1 \mathrm{~L}$ aquades, kemudian dipanaskan hingga mendidih diatas hot plate sambil dihomogenkan dengan menggunakan magnetic stirrer dan ditutup dengan aluminium foil, kedua media tersebut disterilisasikan dengan autoklaf pada suhu $121^{\circ} \mathrm{C}$ selama 15 menit dan tekanan $2 \mathrm{~atm}$ (Irianto, 2006).

\section{Pembuatan Ekstrak Etanol Buah Pepaya}

1000 gr simplisia buah pepaya dilakukan ekstraksi dengan metode maserasi dengan pelarut etanol 96\% sampai simplisia terendam sepenuhnya selama 7 hari dikocok dan diaduk sesekali, disaring. Selanjutnya dilakukan evaporasi etanol dengan menggunakan rotary evavorator dan diperoleh hasil berupa ekstrak kental etanol buah pepaya (Ma'rufah, 2018). 


\section{Pembuatan Sediaan Sabun Cair}

Formulasi pembuatan sediaan sabun cair yaitu 10 gr minyak jarak dicampur dengan 10 gr minyak zaitun dan minyak kelapa, diaduk perlahan hingga homogen, larutan $\mathrm{KOH}$ dengan konsetrasi 10\% ditambahkan sedikit demi sedikit kedalam campuran minyak pada suhu $60-70^{\circ} \mathrm{C}$ hingga terbentuk pasta, ditambahkan 2 gr asam stearat yang telah dilelehkan dan diaduk hingga homogen. Kemudian dimasukkan 0,02 gr BHT dan 3 gr HPMC yang telah dikembangkan dalam $\pm 3 \mathrm{ml}$ akuades panas, lalu ditambahkan $10 \mathrm{gr}$ gliserin. Selanjutnya ditambahkan ekstrak buah pepaya dengan variasi konsentrasi. Kemudian ditambahkan aquades hingga $50 \mathrm{ml}$, diaduk hingga homogen dan dimasukkan kedalam wadah (Sari R, 2017).

\section{Pengujian kualitas sabun cair}

Uji organoleptik yang dilakukan merupakan uji fisik dari sabun cair meliputi warna, aroma, dan bentuk. Pengujian $\mathrm{pH}$ dilakukan dengan menggunakan indikator universal. Indikator universal dicelup kedalam sampel. Tinggi busa, diambil sampel sebanyak $1 \mathrm{ml}$, dimasukkan ke dalam tabung reaksi, kemudian ditambahkan akuades sampai $10 \mathrm{ml}$, dikocok dengan membolak-balikan tabung reaksi, lalu segera diukur tinggi busa yang dihasilkan. Lalu, tabung didiamkan selama 15 menit, kemudian diukur lagi tinggi busa yang dihasilkan setelah 15 menit.

uji busa $=\frac{\text { tinggi busa akhir }}{\text { tinggi busa awal }} \times 100 \%$

Penetapan bobot jenis menggunakan alat piknometer. Piknometer kosong ditimbang dan dicatat bobotnya. Kemudian piknometer diisi air dan ditimbang, lalu dimasukkan sampel sabun dan ditimbang.

\section{Pengujian daya hambat pertumbuhan bakteri terhadap sabun cair dari ekstrak} buah pepaya

Pengujian daya antibakteri menggunakan metode disc diffusion. Bakteri uji diinokulasikan pada media nutrien agar (NA), kertas cakram ukuran $6 \mathrm{~mm}$ dicelupkan kedalam sampel sabun cair, kemudian diletakkan diatas permukaan media. Kemudian diinkubasi pada suhu $35 \pm 2^{\circ} \mathrm{C}$ selama 18 - 24 jam lalu diamati zona hambat yang terbentuk, yang diinterprestasikan dengan melihat daerah bening disekitar cakram yang menunjukkan bahwa tidak adanya pertumbuhan bakteri (Kumar, 2016).

\section{Hasil dan Pembahasan \\ Hasil Skrining Fitokimia}

Seperti yang terlihat pada tabel 2 , hasil skrining serbuk simplisia buah pepaya (Carica papaya L) menunjukan hasil positif pada senyawa alkaloid, flavonoid, tanin, saponin.

\section{Formulasi sediaan sabun cair}

Sabun cair terdiri dari basis dan zat aktif. Pembuatan sabun cair diawali dengan mencampurkan minyak jarak, minyak zaitun dan minyak kelapa, diaduk perlahan hingga homogen. Pencampuran minyak dan $\mathrm{KOH}$ (Kalium hidroksida) dilakukan terlebih dahulu karena kedua bahan tersebut berfungsi sebagai pembentuk basis sabun. Campuran tersebut diaduk pada suhu $60^{\circ} \mathrm{C}-70^{\circ} \mathrm{C}$ agar reaksi penyabunan dapat berjalan dengan baik, karena jika pengadukan dilakukan diatas suhu tersebut maka dapat menyebabkan 
sediaan menjadi berbusa dan meluap dan apabila dilakukan dibawah suhu tersebut, maka akan menyebabkan sediaan menjadi tidak homogen. Pengadukan dilakukan hingga terbentuk pasta, dan ditambahkan asam stearat (Sari R, 2017).

Selanjutnya BHT (Butylated hydroxytoluene) yang berfungsi sebagai antioksidan untuk menjaga stabilitas dari sediaan sabun, dan HPMC (Hidroksipropil metilselulosa) yang berfungsi sebagai pengental sediaan sabun, ditambahkan. Adapun gliserin yang ditambahkan sebagai pelembut (humektan) sediaan sabun sehingga dapat memberikan kelembapan pada kulit (Sari R, 2017). Serta tambahkan sampel ekstrak buah pepaya zat aktif sebagai antibakteri. Penambahan zat aktif dilakukan terakhir untuk menjaga stabilitas dan homogenitas sediaan yang terbentuk. Kemudian ditambahkan akuades hingga volumenya mencapai $50 \mathrm{ml}$ lalu diaduk hingga homogen dan dimasukkan kedalam wadah dan tertutup rapat.

\section{Hasil uji kualitas sabun cair}

Dari hasil uji organoleptik berbagai formula, pada formula F0 warna pada sediaan yaitu berwarna kuning karena diakibatkan dalam formula terdapat minyak zaitun, minyak kelapa, minyak jarak yang membuat sediaan berwara kuning dan juga tidak ada penambahan dari ekstrak etanol buah pepaya, sedangkan pada formula F1, F2, F3, F4, dan F5 dikarenakan adanya penambahan dari ekstrak etanol buah pepaya sehingga mengakibatkan warnanya menjadi coklat tua. Bentuk dari sediaan formula F0, F1, F2, F3, F4, dan F5 yaitu berbentuk cairan homogen, yang mana formula sabun tercampur rata, tidak terbetuk pemisahan antara minyak dan air. Dari hasil uji tersebut diketahui bahwa pengujian organoleptik ini sesuai dengan syarat mutu sabun cair SNI 06-4085-1996.

\section{Uji pH}

Nilai $\mathrm{pH}$ merupakan nilai yang menunjukan derajat keasaman suatu bahan. Derajat keasaman $(\mathrm{pH})$ merupakan parameter penting pada produk kosmetik, karena $\mathrm{pH}$ dapat mempengaruhi daya absorbsi kulit. Secara umum, produk sabun cair memiliki $\mathrm{pH}$ yang cenderung basa, hal ini dikarenakan bahan dasar penyusun sabun cair yaitu $\mathrm{KOH}$ bersifat basa kuat. Nilai $\mathrm{pH}$ sabun yang rendah dapat menyebabkan peningkatan daya absorbsi sabun pada kulit sehingga dapat menyebabkan iritasi pada kulit, sedangkan $\mathrm{pH}$ yang terlalu tinggi juga dapat menyebabkan iritasi pada kulit (Hernani, 2010).

Berdasarkan hasil pengamatan terhadap sediaan sabun cair dari ekstrak etanol buah pepaya dengan konsentrasi, F0, F1, F2, F3, F4, dan F5 diketahui pH yang didapatkan dari keseluruhan konsentrasi yaitu 7. Nilai $\mathrm{pH}$ yang dihasilkan masuk dalam rentang $\mathrm{pH}$ yang disyaratkan oleh SNI (Standar Nasional Indonesia) untuk sabun cair standar yang telah ditetapkan yakni 6-8, sehingga aman untuk diaplikasikan pada kulit karena pada $\mathrm{pH}$ tersebut diharapkan tidak terjadi iritasi pada kulit SNI 06-4085-1996.

\section{Uji Tinggi Busa}

Busa merupakan salah satu parameter yang paling penting dalam menentukan mutu produk-produk kosmetik terutama sabun. Tujuan pengujian busa adalah untuk melihat daya busa dari sabun cair. Busa yang stabil dalam waktu lama lebih diinginkan karena busa dapat membantu membersihkan tubuh (Pradipto, 2009).

Pada pengujian ini tinggi busa yang didapatkan F0 paling rendah yaitu 33,3\% dan paling efektif yaitu terletak pada F3 yaitu 75\%. Hasil uji tinggi busa sampel yang diperoleh dibandingkan dengan konsentrasi disetiap sabun cair karena belum ada standar SNI yang menentukan rentang nilai stabilitas busa.

\section{Uji Bobot Jenis}

Bobot jenis merupakan perbandingan relatif antara massa jenis suatu zat dengan massa jenis air murni pada volume dan suhu yang sama (SNI 06-4085-1996). Pengukuran bobot jenis bertujuan untuk menentukan mutu dan melihat kemurnian dari suatu senyawa, dalam hal ini khususnya sabun cair yang dihasilkan. Penetapan bobot jenis dilakukan 
menggunakan alat piknometer karena tepat dan praktis serta dapat digunakan untuk mengukur bobot jenis suatu zat cair dan zat padat (Sari R, 2017).

Nilai bobot jenis yang diperoleh dari penelitian adalah $1,02-1,04 \mathrm{~g} / \mathrm{ml}$. Hasil dari bobot jenis sediaan sabun cair pada penelitian ini dibandingkan dengan standar yang telah ditetapkan SNI 06-4085-1996 yaitu 1,01-1,10 g/ml. Dengan demikian hasil dari bobot jenis sabun cair pada penelitian ini memenuhi standar dan diharapkan dapat mudah dibersihkan dengan air mengalir karena sediaan sabun cair memiliki bobot jenis yang mendekati bobot jenis air. Tidak ada perubahan bobot jenis yang signifikan antar formula F0 dengan formula yang lain. Dengan demikian menunjukan bahwa ekstrak etanol buah pepaya dapat difungsikan dalam pembuatan sabun cair.

\section{Hasil uji aktivitas daya zona hambat pertumbuhan bakteri staphylococcus aureus terhadap sabun cair ekstrak etanol buah pepaya}

Penentuan hasil uji aktivitas antibakteri sabun cair ekstrak etanol buah pepaya dilakukan dengan metode disc difusion menggunakan kertas cakram. Kemudian zona bening yang terbentuk disekitar kertas cakram diukur diameternya. Sensitifitas bakteri terhadap antibakteri dipengaruhi oleh struktur dinding sel bakteri, bakteri gram positif cenderung lebih sensitif terhadap antibakteri, karena struktur dinding sel bakteri gram positif lebih sederhana sehingga memudahkan senyawa antibakteri untuk masuk kedalam sel bakteri gram positif ( Kusmayati dan Agustini, 2007). Ekstrak etanol buah pepaya yang mengandung senyawa antibakteri alkaloid, flavonoid, tanin, saponin yang mampu menghambat lebih besar. Proses ekstraksi senyawa antibakteri juga berpengaruh terhadap aktivitasnya. Pada pengukuran aktivitas antibakteri sabun cair ekstrak buah pepaya (Carica papaya L.) terhadap Staphylococcus aureus formula yang paling efektif dalam menghambat pertumbuhan bakteri yaitu pada formula F2 dimana memiliki rata-rata daya hambat sebesar 17,6 mm yang dikategorikan kuat dan menunjukkan efek antibakteri paling besar dalam menghambat pertumbuhan bakteri Staphylococcus aureus.

Adanya perbedaan zona bening yang terjadi oleh senyawa antibakteri terhadap bakteri uji, kemungkinan disebabkan oleh kemampuan atau respon dari masing-masing bakteri dalam melawan senyawa antibakteri. Hal ini sesuai dengan Herborne (2003) yang menyatakan bahwa aktivitas daya hambat optimum atau efektif yang disebabkan zat antibakteri terhadap pertumbuhan suatu bakteri tertentu akan terjadi jika diberikan perlakuan yang optimum, tidak bergantung kepada besar kecilnya konsentrasi ekstrak tersebut. Dewi (2010) juga menyatakan adanya perbedaan kecepatan difusi senyawa antibakteri pada media agar serta konsentrasi yang berbeda juga akan memberikan diameter zona hambat yang berbeda.

Berdasarkan hasil pengukuran aktivitas antibakteri yang terlihat pada Gambar 1 diperoleh F0 sebagai kontrol negatif memiliki diameter zona bening sebesar $6 \mathrm{~mm}$ yang masuk dalam kategori lemah, F1 memiliki diameter bening sebesar $6,3 \mathrm{~mm}$ yang juga masuk kategori lemah, F2 memiliki diameter bening sebesar 17,6 mm yang masuk dalam kategori kuat, F3 memiliki diameter bening sebesar $14,3 \mathrm{~mm}$ yang juga masuk dalam kategori kuat, F4 memiliki diameter bening sebesar 10,3 mm masuk dalam kategori sedang, F5 memiliki diameter bening sebesar $10 \mathrm{~mm}$ yang juga masuk dalam kategori sedang. Dari gambar 4.1 dapat diperoleh bahan formulasi yang paling efektif dan menghambat pertumbuhan bakteri adalah F2 dengan diameter zona bening sebesar 17,6 mm yang dapat dikategorikan kuat.

\section{Kesimpulan}

Berdasarkan hasil penelitian yang dilakukan mengenai efek antibakteri sabun cair ekstrak etanol buah pepaya (carica papaya L.) terhadap pertumbuhan bakteri Staphylococcus aureus diperoleh bahwa kualitas sabun cair ekstrak etanol buah pepaya 
telah memenuhi syarat mutu SNI 06-4085-1996. Warna, aroma, bentuk cair homogen, $\mathrm{pH}$ 7, bobot jenis 1,02-1,04 gr/ml. Zona bening sediaan sabun cair ekstrak etanol buah pepaya (Carica papaya L.) terhadap bakteri Staphylococcus aureus yaitu pada formula F0 kategori lemah, F1 kategori lemah, F2 kategori kuat, F3 kategori kuat, F4 kategori sedang, dan F5 kategori sedang. Formulasi sabun cair ekstrak buah pepaya yang paling efektif dalam menghambat pertumbuhan bakteri Staphylococcus aureus adalah F2 dengan zona bening $17,6 \mathrm{~mm}$.

\section{Referensi}

Depkes RI. 1995. Farmakope Indonesia, Edisi IV. Jakarta: Departemen Kesehatan RI.

Dewi, F.K. 2010. Aktivitas antibakteri ekstrak etanol buah mengkudu (Morinda citrifolia, Linnaeus) terhadap bakteri pembusuk daging segar. Skripsi. Surakarta. Universitas sebelas maret.

Doughari J, H, Elmahmood A.M, and Manzara S. 2007. "Studies on the Antibacterial Activity of Root Extracts of Carica papaya L". African Journal of Microbiology. Research pp. 037-041.

Farnsworth, N.R. 1996. "Biological and phytochemical screening of plants". Journal of Pharaceitical Sciences. Vol 55(3) : hal. 225-276.

Gill, S., 2015. The Power of Papaya. Available online at: http://www.nutrionlinel. co.uk/LinkClick.aspx?fileticket $=$ RD56NvsrN71\%3D\&tabidid=710\&mid=1255 [diakses Desember 2018].

Harborne, J.B., 2003. Metode Fitokimia: Penentuan Cara Modern Menganalisis Tumbuhan. ITB. Bandng.

Hernani, Bunasor, T. K., Fitrianti. 2010. "Formula sabun transparan antijamur dengan bahan aktif ekstrak lengkuas (Alpinia galanga L. Swartz)”. Bul. Litro. Vol 21 (2): hal. 192-195.

Irianto, K. 2006. Mikrobiologi, Menguak Dunia Mikroorganisme Jilid 2. Bandung. Yrama Widya.

Kumar, S. 2016. Essentials of Microbiology. Jaypee Brothers Medical Publishers, New Dehli. pp. 560-561.

Kusmayati dan Agustin, N. W. R. 2007. "Uji aktivitas senyawa antibakteri dari mikroalga (Porphyridium cruentum)". Biodiversitas. Vol 8 (1): hal. 48-53.

Ma'rufah dan Adib, M. 2018. "Ekstrak Buah Pepaya (Carica papaya L) Meningkatkan Kadar Catalase dan Glutathione Hati Tikus yang Terpaparlead Acetate". Fakultas Ilmu Kesehatan Universitas Maarif Hasyim Latif Sidoarjo. Jurnal Sain Healt Vol. 2 (1): hal. 8-12.

Milind P and Gurditta. 2011. "Basketful Benefits of Papaya". Internasional Research Journal of Pharmacy. Vol 2 (7): hal. 6-12.

Nirosha, N and Manganalanayaki R. 2013. "Antibacterial Activity of Leaves and Steam Extract of Carica papaya L.". IJAPBC. Vol 2(3): hal.473-476.

Paradipto, M. 2009. Pemanfaatan minyak jarak pagar (Jatropa curcas L) sebagai bahan dasar sabun mandi. Skripsi. Bogor. Institus Pertanian Bogor.

Sari, R dan Ferdinan, A. 2017. Pengujian aktivitas antibakteri sabun cair dari ekstrak kulit daun lidah buaya. Skripsi. Pontianak. Fakultas Kedokteran Universitas Tanjungpura.

Tjitrosoepomo, G. 2005. Taksonomi Tumbuhan Obat-obatan. Yogyakarta. Gajah Mada University Press. 